\title{
SUGARS IN THE BLOOD AND URINE OF CHILDREN FOLLOWING THE INGESTION OF DISACCHARIDES
}

\author{
BY \\ J. C. HAWORTH \\ From The Winnipeg Children's and General Hospitals and the Department of Paediatrics, \\ University of Manitoba
}

(RECEIVED FOR PUBLICATION MARCH 29, 1960)

It has previously been shown that reducing sugars are frequently excreted in the urine by mature and premature newborn babies (Haworth and McCredie, 1956; Haworth and MacDonald, 1957). Other workers, using paper chromatographic methods, have also found small amounts of sugars in the urines of children and usually higher concentrations of lactose and galactose in urines from young babies (Woolf, 1951; Apthorp, 1957; Bickel, 1959). Coant, Glowacki and Reardon (1959) found a high urinary excretion rate of sugars by premature babies which could be correlated with the amount of lactose in the feedings.

This paper describes further observations on sugars in the urine and blood of newborn babies and older children following the oral ingestion of different disaccharides.

\section{Analytical Methods}

The chromatographic technique employed for the separation of sugars in blood and urine was the same as that used previously (Haworth and McCredie, 1956; Haworth and MacDonald, 1957), being a modification of the method originally described by Williams (1954). The filter papers were bisected after removal from the solvent and one half was sprayed with a benzidine developer and the other half with a phloroglucinol reagent (Horrocks and Manning, 1949). Glucose, fructose, lactose, galactose and pentoses were identified by the former reagent and sucrose by the latter. With a double application of the test substance, monosaccharides could be identified in concentrations of about $10 \mathrm{mg} . / 100 \mathrm{ml}$. and disaccharides in rather lower concentrations.

Blood sugar estimations were performed by the method of King (1951).*

Part I: Sugars in Urine and Blood of Mature and Premature Babies Following Ingestion of Disaccharides

Clinical Material and Methods. The sugars lactose, sucrose or maltose were fed to 47 newborn babies at

* It has been found that this method measures $100 \%$ glucose, $85 \%$ fructose, $68 \%$ galactose and $28 \%$ lactose. the Women's Pavilion of the General Hospital, Winnipeg The group was unselected, except that males were preferred to females because of the greater ease of urine collection. There were 39 males and eight females. Twenty-eight of the babies were mature and 19 were premature (birth weight $5 \frac{1}{2} \mathrm{lb}$. or less). All the babies were considered healthy with the exception of two (one mature and one premature) who developed hyperbilirubinaemia which was not due to any demonstrable blood incompatibility between mother and child. Neither, however, required exchange transfusion. Five other babies developed mild 'physiological' jaundice. The birth weights of the babies varied between $3 \mathrm{lb} .1 \mathrm{oz}$. and $11 \mathrm{lb} .6 \mathrm{oz}$. and the estimated gestation of the premature babies was from 30 to 40 weeks. The ages of the babies at the time of the tests were between 1 and 23 days.

The sugars were fed in doses ranging from 0.5 to $4.2 \mathrm{~g}$. per $1 b$. at the baby's usual feeding time, i.e. three or four hours after the previous feed. In 10 instances the test sugar was given in the baby's usual feed (expressed breast milk or evaporated milk) and the additional sugar in the feed was taken into account in calculating the total dose given. In all the other experiments the sugar was given in water. The sugars were administered to several of the smaller premature babies by gavage. The dose of the sugar given was assessed approximately, allowances being made for the baby who was unable to take the total volume of fluid and for minor regurgitations. Tests were abandoned in babies who vomited.

Test tubes for urine collection were applied to the babies one hour before the test feed and specimens collected in this interval were termed 'a.c.' urines. Test tubes were reapplied at the end of the feeds and left in place until the babies voided. These specimens were the 'p.c.' urines. Some babies did not pass urine for as long as six hours after the test feed and, because it was not justifiable to withhold feedings longer than this, some 'p.c.' urines were not obtained. It was also not possible to collect the 'a.c.' urine in every instance.

Capillary blood was collected for chromatography before the test feed and one and two hours after the conclusion of the feed. In a few tests half-hour and threehour specimens were also taken.

Results. Sixty-two tests were conducted on the 47 babies and the results are summarized in Tables 1 to 4 . 
TABLE 1

SUGAR CONTENT OF A.C. URINES FROM MATURE AND PREMATURE BABIES

\begin{tabular}{|c|c|c|c|c|c|}
\hline & & & $\begin{array}{c}\text { Urines } \\
\text { Containing } \\
\text { Sugar }\end{array}$ & $\begin{array}{c}\text { Urines } \\
\text { Containing } \\
\text { No Sugar }\end{array}$ & Total \\
\hline $\begin{array}{l}\text { Mature } \\
\text { Premature }\end{array}$ & . & $\ddot{*}$ & $\begin{array}{l}5 \\
8 \\
\end{array}$ & $\begin{array}{l}20 \\
16 \\
\end{array}$ & $\begin{array}{l}25 \\
24 \\
\end{array}$ \\
\hline Totals & . & .. & 13 & 36 & 49 \\
\hline
\end{tabular}

URINES. Table 1 shows the sugar content of the 49 'a.c.' urines that were collected during the 62 tests. Thirteen of these urines contained one or more sugars and 36 contained no sugar. Two urines contained lactose alone, four galactose alone, five galactose and lactose, one glucose alone and one glucose and lactose. There was no statistically significant correlation between the proportions of urines which contained sugars and the maturity of the babies.

Table 2 shows the number of observations obtained by feeding lactose, sucrose and maltose and the subsequent urine sugar content. There was no statistical difference in the sugar excretion rate of the mature and premature babies. It is seen that following a feed of lactose, this sugar was found in eight of the 12 urines excreted by the mature babies and in six of 15 urines excreted by the premature babies. After sucrose feeding, three of six urines from mature babies and two of eight urines from the prematures contained sucrose. Monosaccharides were similarly found as frequently in the urines of the mature as of the premature infants. After receiving a feed of maltose, none of the 14 'p.c.' urines showed this sugar, although, nine urines contained glucose.

There was no correlation between the dose of the sugar administered and the subsequent urinary sugar content as shown in Table 3. The premature babies received on the whole higher doses than the mature babies. For instance, of 17 premature babies who received lactose on one or more occasions, eight received less than $2 \mathrm{~g}$. per $\mathrm{lb}$. and nine 2 or more g. per lb., while 13 mature babies received the lower dose and only one the higher.

Pentoses were found in two urines. These were not identified with certainty but may have been xylulose. Xylose was not found on any occasion in this series. The concentration in which the sugars were found in the 'p.c.' urines are expressed in Table 4. It may be seen that sugars were most commonly present in concentrations below $200 \mathrm{mg}$./100 ml., but glucose, fructose and sucrose were occasionally found in higher concentrations. A 'trace' indicates that there was a very clear but faint band on the filter paper, showing monosaccharides in a concentration of about $10 \mathrm{mg} . / 100 \mathrm{ml}$. and disaccharides in a somewhat lower concentration. There was no

TABLE 2

SUGARS FOUND IN THE BLOOD AND URINE AFTER FEEDING LACTOSE, SUCROSE OR MALTOSE TO 47 NEWBORN BABIES

\begin{tabular}{|c|c|c|c|c|c|c|c|c|c|c|c|}
\hline & & & \multicolumn{3}{|c|}{ Lactose } & \multicolumn{3}{|c|}{ Sucrose } & \multicolumn{3}{|c|}{ Maltose } \\
\hline & & & $\begin{array}{l}\text { Mature } \\
\text { Babies }\end{array}$ & $\begin{array}{c}\text { Premature } \\
\text { Babies }\end{array}$ & Total & $\begin{array}{l}\text { Mature } \\
\text { Babies }\end{array}$ & $\begin{array}{c}\text { Premature } \\
\text { Babies }\end{array}$ & Total & $\begin{array}{l}\text { Mature } \\
\text { Babies }\end{array}$ & $\begin{array}{c}\text { Premature } \\
\text { Babies }\end{array}$ & Total \\
\hline No. of Patients & . & $\cdots$ & 14 & 13 & 27 & 7 & 6 & 13 & 9 & 6 & 15 \\
\hline $\begin{array}{l}\text { Urines: } \\
\text { No. of tests } \\
\text { No. examined } \\
\text { Glucose .. } \\
\text { Galactose } \\
\text { Lactose . . } \\
\text { Fructose . . } \\
\text { Sucrose . } \\
\text { Pentose . } \\
\text { No sugar }\end{array}$ & $\begin{array}{l}\cdots \\
\cdots \\
\cdots \\
\cdots \\
\cdots \\
\cdots \\
\cdots\end{array}$ & $\begin{array}{l}\cdots \\
\cdots \\
\cdots \\
\cdots \\
\cdots \\
\cdots \\
\cdots\end{array}$ & $\begin{array}{r}14 \\
12 \\
5 \\
6 \\
8 \\
0 \\
0 \\
0 \\
3\end{array}$ & $\begin{array}{r}17 \\
15 \\
0 \\
11 \\
6 \\
1 \\
0 \\
0 \\
2\end{array}$ & $\begin{array}{r}31 \\
27 \\
5 \\
17 \\
14 \\
1 \\
0 \\
0 \\
5\end{array}$ & $\begin{array}{l}7 \\
6 \\
0 \\
0 \\
0 \\
5 \\
3 \\
0 \\
1\end{array}$ & $\begin{array}{l}9 \\
8 \\
5 \\
0 \\
0 \\
4 \\
2 \\
1 \\
2\end{array}$ & $\begin{array}{r}16 \\
14 \\
5 \\
0 \\
0 \\
9 \\
5 \\
1 \\
3\end{array}$ & $\begin{array}{l}9 \\
9 \\
5 \\
0 \\
1 \\
0 \\
0 \\
1 \\
4\end{array}$ & $\begin{array}{l}6 \\
5 \\
4 \\
0 \\
1 \\
0 \\
0 \\
0 \\
1\end{array}$ & $\begin{array}{r}15 \\
14 \\
9 \\
0 \\
2 \\
0 \\
0 \\
1 \\
5\end{array}$ \\
\hline $\begin{array}{l}\text { Blood: } \\
\text { No. of tests* } \\
\text { Glucose ... } \\
\text { Other sugars }\end{array}$ & $\begin{array}{l}\cdots \\
\cdots \\
\cdots\end{array}$ & $\begin{array}{l}\cdots \\
\cdots \\
\cdots\end{array}$ & $\begin{array}{l}4 \\
4 \\
0\end{array}$ & $\begin{array}{r}14 \\
14 \\
0\end{array}$ & $\begin{array}{r}18 \\
18 \\
0\end{array}$ & $\begin{array}{l}1 \\
1 \\
0\end{array}$ & $\begin{array}{l}5 \\
5 \\
0\end{array}$ & $\begin{array}{l}6 \\
6 \\
0\end{array}$ & $\begin{array}{l}0 \\
0 \\
0\end{array}$ & $\begin{array}{l}2 \\
2 \\
0\end{array}$ & $\begin{array}{l}2 \\
2 \\
0\end{array}$ \\
\hline
\end{tabular}

* Fasting and usually one- and two-hour specimens.

TABLE 3

SUGAR CONTENT OF 'P.C.' URINES RELATED TO THE DOSE OF SUGAR ADMINISTERED

\begin{tabular}{|c|c|c|c|c|c|}
\hline Dose & Sugar Given & No. of Urines & $\begin{array}{l}\text { No. of Urines Con- } \\
\text { taining No Sugar }\end{array}$ & Disaccharide* & Monosaccharide* \\
\hline $\begin{array}{c}<2.0 \mathrm{~g} . / \mathrm{lb} . \\
2.0 \mathrm{~g} . / \mathrm{lb} . \text { or more }\end{array}$ & $\begin{array}{l}\text { Lactose } \\
\text { Sucrose } \\
\text { Lactose } \\
\text { Sucrose }\end{array}$ & $\begin{array}{r}18 \\
8 \\
9 \\
6\end{array}$ & $\begin{array}{l}3 \\
3 \\
2 \\
0\end{array}$ & $\begin{array}{r}11 \\
3 \\
3 \\
2\end{array}$ & $\begin{array}{r}11 \\
5 \\
11 \\
9\end{array}$ \\
\hline
\end{tabular}

* Indicates the number of sugars found in the urines, i.e. several urines contained more than one sugar. 
correlation between the concentration of sugar in the urine and the dose administered or the maturity of the baby. Two of the babies excreting the largest amount of sucrose were mature and had received less than $2 \mathrm{~g}$. per lb. sucrose, the other was a premature who had taken more than $2 \mathrm{~g}$. per $\mathrm{lb}$.

The jaundiced babies behaved no differently from the other babies with respect to sugar excretion.

TABLE 4

CONCENTRATIONS OF SUGARS IN P.C. URINES

\begin{tabular}{|c|c|c|c|c|c|}
\hline \multirow{2}{*}{$\begin{array}{l}\text { Concentration } \\
\text { (mg./100 ml.) }\end{array}$} & \multicolumn{5}{|c|}{ No. of Urines Containing Sugars } \\
\hline & Glucose & $\begin{array}{c}\text { Galac- } \\
\text { tose }\end{array}$ & Lactose & $\begin{array}{l}\text { Fruc- } \\
\text { tose }\end{array}$ & Sucrose \\
\hline $\begin{array}{c}\text { Trace } \ldots \\
<100 \ldots \\
100-200 \\
>200 \quad \ldots\end{array}$ & $\begin{array}{l}5 \\
4 \\
8 \\
2 \\
\end{array}$ & $\begin{array}{r}7 \\
5 \\
5 \\
- \\
\end{array}$ & $\begin{array}{r}3 \\
5 \\
8 \\
-\end{array}$ & $\begin{array}{c}\overline{-} \\
9 \\
1\end{array}$ & $\frac{1}{1}$ \\
\hline Totals & 19 & 17 & 16 & 10 & 5 \\
\hline
\end{tabular}

BLoods. Bloods were chromatographed during 26 tests on 19 babies and, as shown in Table 2, no sugar other than glucose was found.

\section{Part II: Sugars in Urine and Blood of Older Children Following Ingestion of Disaccharides}

Clinical Material and Methods. The subjects were 47 in-patients in the Children's Hospital, Winnipeg, ranging in age from 5 months to 15 years. There were 24 males and 23 females. The children were carefully selected and were as 'normal' as possible. Many of the children were suffering from minor skin infections, some were in hospital for investigation of such conditions as convulsions and others were convalescent from infections such as pneumonia. None of the children had had elevated temperatures for 48 hours before the tests, none were taking drugs, such as hormones, which might have had an effect upon their metabolism and none were suffering from any metabolic disorder. Patients with gastro-intestinal disease were not included with the exception of four children who were carriers of $E$. coli or salmonella organisms. These four children had had normal bowel movements for at least one week preceding the tests and were all said to have normal appetites. They were receiving standard hospital diets but otherwise the carbohydrate intake before the tests was not controlled.

The tests were performed at 9 a.m. after the subjects had been fasted from midnight. After the fasting blood specimens had been taken the children drank the sugars dissolved in water flavoured with lemon. The dose of the sugar administered was $1 \mathrm{~g}$. per $\mathrm{lb}$. body weight, the minimum dose $15 \mathrm{~g}$. and the maximum $50 \mathrm{~g}$. Further blood specimens were initially taken half, one and two hours after the feed and in later experiments an additional quarter-hour specimen was also taken. These bloods were chromatographed and analysed for total sugar content. From eight of the children, five and 10-minute bloods were also analysed for total sugar.
Urines for chromatography were collected one hour after the test feed, but in some of the children no sample was obtainable.

Five additional 'normal' children (four males and one female) whose ages ranged from 6 weeks to 21 months were given lactose by mouth under the same conditions as detailed above. Immediately following the feed, urine collection was started and continued for eight hours. An approximate quantitative estimation by paper chromatography was made of the sugars in each of the urines.

Results. Eighteen children received lactose, 22 sucrose, and seven maltose.

The results of paper chromatographic analysis of the urines and blood are shown in Table 5. It can be seen that 12 of the 15 urines obtained from the 18 children who were given lactose contained sugars (lactose was present in six of them) and only three contained no sugar. In an 18-month-old girl a trace of lactose was found in the 15-, 30- and 60-minute blood samples, but not in the fasting and two-hour samples. No lactose was found in the urine of this child. In 16 urines, collected from 22 children who were given sucrose, fructose was identified in eight, five of which also contained sucrose. The remaining eight urines contained no sugar.

Sucrose and fructose were found together in the blood of four children. These were different children from the five who excreted this combination of sugars in the urine, although two of these five children showed fructose alone in the blood. Glucose was naturally also present in all the blood samples chromatographed. Maltose was not found in the blood or urine of any of the seven children who had received this sugar. A trace of glucose was present in one of the seven urines, the others contained no sugar.

The concentrations of the sugars found in the urine were all between 50 and $100 \mathrm{mg}$. $/ 100 \mathrm{ml}$. except for a 5 -month-old baby who excreted approximately $120 \mathrm{mg}$. of lactose per $100 \mathrm{ml}$. The sucrose and/or fructose

TABLE 5

SUGARS IN BLOOD AND URINE AFTER FEEDING LACTOSE, SUCROSE OR MALTOSE TO 47 CHILDREN

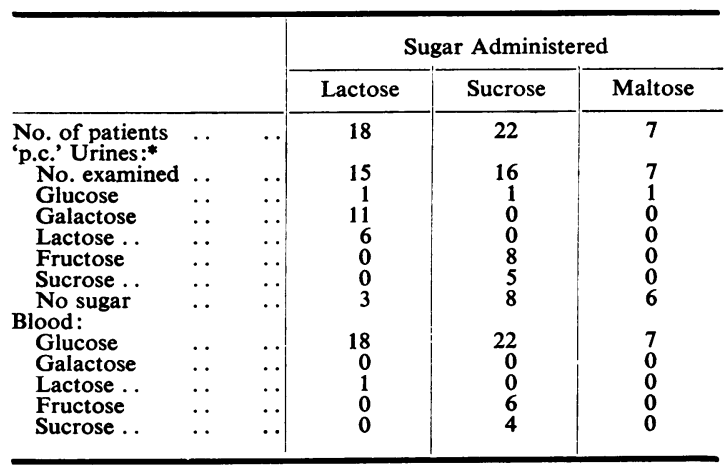

* Figures indicate number of sugars found in the urines, i.e. several urines contained more than one sugar. 
TABLE 6

AGES OF 40 CHILDREN GIVEN LACTOSE AND SUCROSE IN RELATION TO SUGARS FOUND IN BLOOD AND URINE

\begin{tabular}{|c|c|c|c|c|c|c|c|}
\hline $\begin{array}{c}\text { Sugar } \\
\text { Fed }\end{array}$ & Age & $\begin{array}{l}\text { No. of } \\
\text { Cases }\end{array}$ & $\underset{\text { Excreted }}{\text { Sugar }}$ & $\begin{array}{l}\text { No Sugar } \\
\text { Excreted }\end{array}$ & $\begin{array}{l}\text { No Urine } \\
\text { Collected }\end{array}$ & $\underset{\text { in Blood }}{\text { Sugar* }}$ & $\begin{array}{l}\text { No Sugar* } \\
\text { in Blood }\end{array}$ \\
\hline Lactose & $\begin{array}{l}5-11 \mathrm{mths} \\
1-3 \text { yrs } \\
4-8 \text { yrs } \\
>8 \text { yrs }\end{array}$ & $\begin{array}{l}5 \\
6 \\
3 \\
4\end{array}$ & $\begin{array}{l}2 \\
4 \\
2 \\
4\end{array}$ & $\begin{array}{l}1 \\
1 \\
1 \\
0\end{array}$ & $\begin{array}{r}2 \\
1 \\
- \\
\end{array}$ & $\begin{array}{l}0 \\
1 \\
0 \\
0\end{array}$ & $\begin{array}{l}5 \\
5 \\
1 \\
4\end{array}$ \\
\hline Sucrose & $\begin{array}{l}5-11 \mathrm{mths} \\
1-3 \text { yrs } \\
4-8 \text { yrs } \\
>8 \text { yrs }\end{array}$ & $\begin{array}{r}4 \\
10 \\
4 \\
4\end{array}$ & $\begin{array}{l}3 \\
3 \\
2 \\
0\end{array}$ & $\begin{array}{l}0 \\
4 \\
1 \\
3\end{array}$ & $\begin{array}{l}1 \\
3 \\
1 \\
1\end{array}$ & $\begin{array}{l}1 \\
4 \\
1 \\
0\end{array}$ & $\begin{array}{l}3 \\
6 \\
3 \\
4\end{array}$ \\
\hline
\end{tabular}

* Other than glucose.

identified in the blood of six children were only present in 'trace' amounts which corresponded to concentrations of about $20 \mathrm{mg} . / 100 \mathrm{ml}$.

Table 6 shows the ages of the 40 children who were given lactose and sucrose in relation to the sugars found in the urine and blood. The older children who were given lactose excreted sugars to the same degree as the younger and no relation between age and sugar excretion was demonstrated. No sugar, however, was found in the three urines obtained from the four children over the age of 8 years who were given sucrose, and no fructose or sucrose was found in their blood. The five children who excreted sucrose were all under 3 years of age. Sucrose and fructose were found in the blood of an 8-year-old boy, but unfortunately no urine specimen was obtained from this child.

Table 7 and Fig. 1 show the mean blood sugar levels following feeding the three sugars. On 18 occasions blood sugar levels were obtained 15 minutes after the test feed as shown in column 6 of Table 7 and by the separate points in Fig. 1. The 15-minute levels following the administration of lactose were higher than the 30-minute levels, but for the other two sugars the 'peak' was at 30 minutes. The differences between the 30minute levels following the administration of sucrose (143 mg./100 ml.) and lactose (116 mg./100 ml.) are statistically significant $(\mathrm{p}=<0.01)$. The differences between the 30-minute levels of the sucrose and maltose curves, the maltose and lactose curves, and the levels at other time intervals are not statistically significant. Five- and 10-minute blood sugar levels were also obtained in four subjects following the administration of lactose and in four following sucrose. The mean

TABLE 7

MEAN BLOOD SUGAR LEVELS (mg./100 ml.) OF 47 CHILDREN GIVEN LACTOSE, SUCROSE AND MALTOSE BY MOUTH

\begin{tabular}{|c|c|c|c|c|c|c|c|c|}
\hline \multirow{2}{*}{$\underset{\text { Fed }}{\text { Sugar }}$} & \multirow{2}{*}{$\begin{array}{c}\text { No. } \\
\text { of } \\
\text { Tests }\end{array}$} & \multirow{2}{*}{ Fasting } & \multicolumn{6}{|c|}{ Time after Ingestion (min.) } \\
\hline & & & 5 & 10 & 15 & 30 & 60 & 120 \\
\hline $\begin{array}{l}\text { Lactose } \\
\text { Sucrose } \\
\text { Maltose }\end{array}$ & $\begin{array}{r}18 \\
22 \\
7\end{array}$ & $\begin{array}{l}75 \\
77 \\
74\end{array}$ & $\begin{array}{l}101(4) \\
103(4) \\
-\end{array}$ & $\begin{array}{c}108(4) \\
113(4) \\
-\end{array}$ & $\begin{array}{l}128(9) \\
119(6) \\
129(3)\end{array}$ & \begin{tabular}{l|}
116 \\
143 \\
138
\end{tabular} & $\begin{array}{l}109 \\
103 \\
117\end{array}$ & $\begin{array}{l}80 \\
88 \\
80\end{array}$ \\
\hline
\end{tabular}

Numbers in parenthesis indicate the number of children upon whom 5- 10- and 15-minute estimations were obtained.

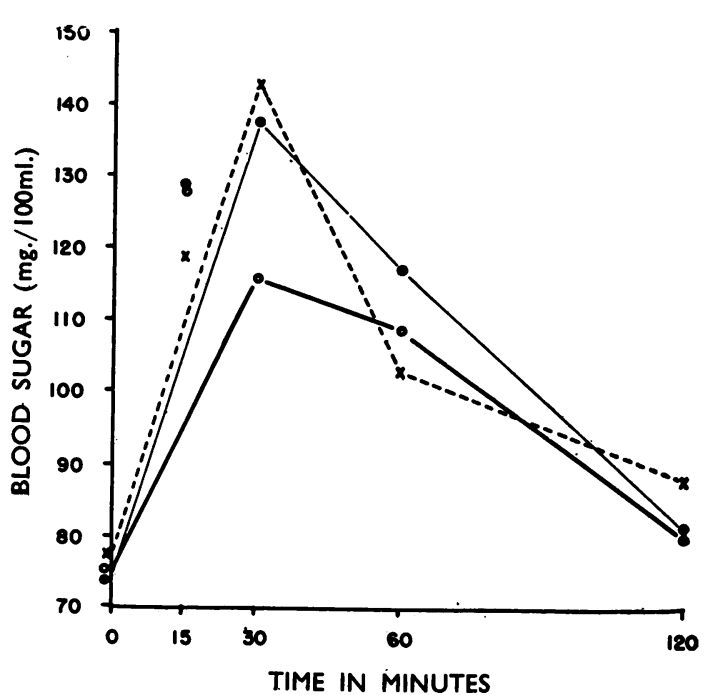

Fig. 1.-Mean blood sugar levels following the oral ingestion of lactose, sucrose and maltose (fastings 15-, 30-, 60- and 120-minute

$\mathrm{O}-\mathrm{O}$ - levels).

$\times$...... $\times$ mean levels after sucrose, all cases (22)

mean levels after maltose, all cases (7)

levels are shown in columns 4 and 5 of Table 7 and the mean blood sugar levels of these eight children are expressed in Fig. 2.

Table 8 shows the approximate amounts of galactose and lactose excreted over an eight-hour period by the five young children who were given lactose by mouth. It can be seen that the total amounts excreted were very small, $120 \mathrm{mg}$. of lactose in the urine of Case 3 being the largest amount found.

\section{Discussion}

The results obtained in Part I confirm the earlier findings that sugars are frequently excreted in the urine of newborn babies (Haworth and McCredie, 
TABLE 8

TOTAL AMOUNTS OF SUGAR EXCRETED OVER EIGHT HOURS BY FIVE CHILDREN FOLLOWING DOSE OF LACTOSE BY MOUTH

\begin{tabular}{|c|c|c|c|c|c|c|c|}
\hline \multirow{2}{*}{$\begin{array}{l}\text { Case } \\
\text { No. }\end{array}$} & \multirow{2}{*}{$\begin{array}{c}\text { Age } \\
\text { (mths) }\end{array}$} & \multirow{2}{*}{ Sex } & \multirow{2}{*}{$\begin{array}{l}\text { Weight } \\
\text { lb. oz. }\end{array}$} & \multirow{2}{*}{$\begin{array}{c}\text { Dose of } \\
\text { Lactose (g.) }\end{array}$} & \multirow{2}{*}{$\begin{array}{l}\text { Volume of } \\
\text { Urine (ml.) }\end{array}$} & \multicolumn{2}{|c|}{ Total Sugar Excreted } \\
\hline & & & & & & Lactose & Galactose \\
\hline $\begin{array}{l}1 \\
2 \\
3 \\
4 \\
5\end{array}$ & $\begin{array}{c}1 \frac{1}{2} \\
6^{2} \\
2^{\frac{1}{4}}\end{array}$ & $\begin{array}{l}\mathbf{F} \\
\mathbf{M} \\
\mathbf{M} \\
\mathbf{M} \\
\mathbf{M}\end{array}$ & $\begin{array}{r}11 \\
17 \\
34 \\
6 \\
11\end{array}$ & $\begin{array}{l}15 \\
17 \\
35 \\
15 \\
20\end{array}$ & $\begin{array}{c}41 \\
49 \cdot 5 \\
97 \\
89 \\
127\end{array}$ & $\begin{array}{c}8 \\
7 \cdot 5 \\
120 \\
18 \\
19\end{array}$ & $\begin{array}{l}8 \\
7 \cdot 5 \\
43 \\
11 \\
19\end{array}$ \\
\hline
\end{tabular}

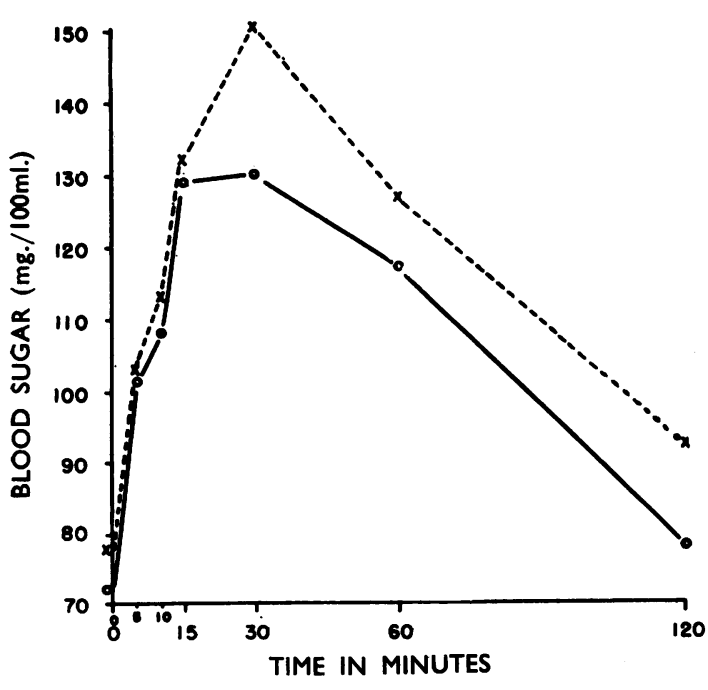

Fig. 2.-Mean blood sugar levels following the oral ingestion of lactose and sucrose (fastings 5-, 10-, 15-, 30-, 60- and 120-minute levels).

O-O mean levels after lactose (4 cases)

$\times$...... $\times$ mean levels after sucrose (4 cases)

1956; Haworth and MacDonald, 1957). Part II shows that older children also frequently excrete sugars after the ingestion of sugars by mouth.

With the exception of the pentoses which were found in two newborn urines, there can be little doubt that the urinary sugars originated from the gut because there was such a close association between the sugar ingested and that subsequently found in the urine. In Part I more urines contained sugars after the sugar feed (Table 2) than those collected before the feed (Table 1). It seems likely that the galactose, glucose and lactose found in 13 of these 49 'a.c.' urines were derived from the milk feeds these babies had received three to four hours before the tests were performed. Tables 2 and 5 show that the sugar fed to the babies in Part $I$ and the older children in Part II had a considerable influence on the type of sugar excreted in the urine. Sucrose was never found unless sucrose had been fed and galactose was never found unless lactose had been fed. In Part I lactose was found in the urine of two babies who had received maltose, but it is again likely that this was the result of preceding milk feeds. Fructose was found on one occasion after a lactose feed, but this baby's previous feed had contained sucrose.

That some lactose may escape hydrolysis in the gut and subsequently appear in the urine has been known for many years (Folin and Berglund, 1922; Winter, 1931; Koehler, Rapp and Hill, 1935). The investigations reported here show that it is a very frequent occurrence in babies and children. Although as much as $200 \mathrm{mg}$. of lactose per $100 \mathrm{ml}$. was found in the urine of some babies, Table 8 indicates that the amount of lactose excreted in the urine during an eight-hour period was only a very small fraction of the total dose given to these five babies.

Galactose, which together with glucose, is released by the hydrolysis of lactose is thought to be transported to the liver where it enters the 'glucose pool'. If the load of galactose entering the liver by the portal vein is too great for that organ to metabolize, some of the sugar will escape into the systemic circulation and because there is no renal threshold for galactose (Hartmann, McCoy, Swarm and Nakasato, 1954), it will be excreted. Rowe (1924) found that $30 \mathrm{~g}$. was the maximum dose of galactose that could be ingested by adults without galactose appearing in the urine. Folin and Berglund (1922) found that the ingestion of only $10 \mathrm{~g}$. could cause sugar to be excreted. Shay, Schloss and Bell (1931), on the other hand, found no correlation between the age, weight or dose given to their subjects and the subsequent amount of galactose excreted in the urine. No relation between the dose of sugar given and the urinary excretion of sugar could be demonstrated in the tests on the babies in Part I (Table 3).

Sucrosuria following the oral ingestion of sucrose has been recognized by other workers (Murschhauser, 
1921; Elmer, Krasowska and Ptaszek, 1939; Lahdensuu, 1947). A dose of sucrose $2 \mathrm{~g}$. per kg. body weight was considered by some to be the upper limit of tolerance. Again, no relation between the dose given and sugar excretion was demonstrated in the observations reported here. Several babies who were given more than $2 \mathrm{~g}$. sucrose per $\mathrm{lb}$. body weight (Table 3 ) and several older children who received $1 \mathrm{~g}$. per $\mathrm{lb}$. did not show sucrosuria. Any sucrose escaping hydrolysis in the gut is evidently treated after absorption as a foreign substance and excreted (Keith, Wakefield and Power, 1932; Keith and Power, 1937). Sucrose was identified in five of 14 urines collected from newborn babies and in five of 16 urines from older children who had received this sugar (Tables 2 and 5). Three of the babies excreted the sugar in a concentration greater than $200 \mathrm{mg}$. per $100 \mathrm{ml}$. (Table 4). Sucrosuria of such a degree, occurring in approximately a third of these children after sucrose feeding, raises doubts as to the significance of the findings of sucrosuria in the cases reported by Reiner and Weiner (1939), Owen and Lewis (1956), and the syndrome of hiatus hernia, mental defect and sucrosuria described by Moncrieff and Wilkinson (1954) and Woodruff (1958). Certainly the degree of sucrosuria exhibited by the children which these authors recorded was no more than that shown by the normal children reported here. Perry, Lippman, Walker and Shaw (1959), who recently reported findings very similar to mine, came to the same conclusion. Moncrieff and Wilkinson (1954) stated that when sucrose and lactose were given together in the diet of their patients, other sugars were excreted more easily in the urine. I have no additional observations to make about this statement except to emphasize that normal children apparently excrete sugars so frequently after sugarcontaining feedings.

It is noteworthy that maltose was never found in either blood or urine following maltose feeds. This is in sharp contrast to the frequency with which the other disaccharides, lactose and sucrose, were found in the urine after feedings with these sugars. I have no satisfactory explanation to offer. It is possible that the maltase secreted by the small bowel may be more efficient than sucrase and lactase, resulting in complete hydrolysis of the maltose into its component glucose molecules. Alternatively it has been suggested that blood may contain some maltase (Long, 1947) so that any of the sugar which escapes hydrolysis in the gut may be split after absorption. It is hoped to conduct further observations upon this subject.

In view of the frequent finding of sucrose, fructose, lactose and galactose in the urines after sugar feeds it is surprising that sugars were not demonstrated more often in the blood. In fact, galactose was not observed in any of the blood samples obtained from 18 babies and 18 older children who were given lactose feeds and lactose was only found on one occasion. Sucrose was not found in the blood of any of the newborn babies who were given this sugar, although sucrosuria occurred in five (Table 2). Of 22 older children who were given sucrose, sucrose and fructose were found in the blood of four. Unfortunately urines were not collected from two of these four children, but in the urines of the other two, no sugar was found in one and fructose in the other. Of five children showing sucrosuria and fructosuria, fructose was found in the blood of two and no sugar other than glucose in the other three. It would be expected that an ingested sugar which has escaped metabolism in the body and been excreted in the urine would be demonstrable in the systemic blood. Conversely, sugar appearing in the peripheral blood should be found in the urine if the sugar is a 'non-threshold' substance which lactose, galactose and sucrose presumably are. The most likely cause for the discrepancy in the blood and urinary findings is that the chromatographic technique used was not sufficiently sensitive to demonstrate low concentrations of sugars in the blood. However, any galactose in the blood of those children who were given lactose feedings must have been present in concentrations lower than about $10 \mathrm{mg}$. per $100 \mathrm{ml}$. or it would have been detected. This is supported by the finding that only very small amounts of galactose were excreted over an eighthour period by the five children upon whom quantitative estimations were performed (Table 8). It may be calculated that the blood levels would be less than $1 \mathrm{mg}$. per $100 \mathrm{ml}$. to give rise to this amount of galactose in the urine, assuming that galactose is a 'non-threshold' substance, even allowing for the lower renal clearance in infancy (Rubin, Bruck and Rapoport, 1949). This is in conflict with the conclusions of Hartmann, Grunwaldt and James (1953) who stated that galactose formed up to $40 \%$ of the total blood sugar in infants after milk feedings. Dormandy, Leak and Grant (1959) reached similar conclusions to those of Hartmann et al. (1953), although employing different analytical methods. It should be pointed out, however, that these two groups of workers only concluded that the bloods they examined contained large amounts of galactose because of the difference between the total sugar and the glucose. Further information has recently been obtained bearing on this subject (Haworth and Ford, 1960). 
There appeared to be little correlation between the ages of the children, the dose of sugar fed to them and the subsequent frequency of sugar excretion or the concentration of the sugar in the urine. The urines from the older children, however, with one exception, contained less than $100 \mathrm{mg}$. per $100 \mathrm{ml}$. of sugar, while higher concentrations were more commonly found in the urines of the newborn babies (Table 4). This may have been because the latter babies received, on the whole, relatively higher doses of sugars than the older children, although Table 3 shows that the dose of sugar administered to the newborn babies appeared to bear no relation to sugar excretion. Sucrose was not found in any of the six urine samples obtained from children over 3 years of age, but little conclusion can be drawn from this especially since fructose and sucrose were found in the blood of an 8-year-old boy from whom, unfortunately, no urine was obtained.

Table 1 shows no significant difference in the sugar content of the urines from mature and premature babies before the test feed and Table 2 shows that premature babies excreted sugars to no greater degree than the mature babies after the sugar feed, and this in spite of the fact that on the whole they received higher doses of sugars. This is not in accord with previous findings that premature babies excreted sugars more often than mature babies (Haworth and MacDonald, 1957). Bickel (1959) also found more sugars in the urine of premature babies especially during the first 10 days of life. In retrospect there may be a valid explanation for the difference in sugar excretion rate between mature and premature babies previously found. The mature babies studied by Haworth and McCredie (1956) were fed by 'demand', and the premature babies (Haworth and MacDonald, 1957) were fed three hourly. Both groups were fed with breast milk, but it seems likely that the bigger babies may have 'demanded' feeds less often than three hourly and unfortunately no record of the times of the feeds of these babies was kept. Since the urinary sugar content has been shown to be closely related to sugar ingestion, if premature babies were fed more often than the mature, this would account for the greater number of urines containing sugar from these babies; the times of urine collection were not correlated with times of feeding.

Concerning the glycaemic response to the oral administration of lactose, sucrose and maltose in Part II (Table 7), several features are worthy of comment. Earlier workers had found that lactose ingestion caused only minimal elevation of the blood sugar (Field, 1919; Folin and Berglund, 1922; Koehler et al., 1935), but these authors were handicapped by inaccurate analytical methods. Greenwald and Pennell (1930) observed that blood sugar curves in infants following the administration of lactose and sucrose closely paralleled that following glucose administration, but the curve following dextri-maltose was lower and more prolonged. The curves shown in Fig. 1 are very different from those shown by Greenwald and Pennell and reveal a rapid rise in blood sugar after the administration of the three sugars. In the case of lactose a 'peak' value 15 minutes after administration of the sugar is shown. Following sucrose and maltose the 'peak' was at 30 minutes. The shape of a blood sugar curve is to some extent dependent upon the frequency of the blood sugar estimations, and it is very possible that the true 'peaks' of the sucrose and maltose curves might have been shown to have been between 15 and 30 minutes if more frequent blood samples had been obtained. Dodds, Fairweather, Miller and Rose (1959) recently commented upon this feature and showed that the standard method of performing a glucose tolerance test, in which samples of blood taken fasting and at 30,60, 90 and 120 minutes, may sometimes show an abnormally flat curve when in fact a more normal type of response is demonstrated if additional samples of blood are taken between 15 and 30 minutes. Table 7 and Fig. 2 show that the blood sugar level had risen by $30 \%$ in as short a time as five minutes after the ingestion of sucrose and lactose by each group of four children. Rabinowitch (1945), Rabinowitch and Mountford (1947) and Dodds et al. (1959) have also demonstrated the rapid rise in blood sugar following sucrose administration and it has now been shown that an equally rapid rise of blood sugar occurs after lactose ingestion. Since sugars are not absorbed to any appreciable degree from the stomach (Long, 1947) and there is no evidence that disaccharides can be hydrolysed proximal to the small bowel, it is indeed remarkable how rapidly sucrose and lactose pass into the small intestine, are hydrolysed, absorbed and reach the systemic circulation. Unfortunately, no five- and 10-minute blood samples were obtained following maltose, although 15-minute blood sugar levels following the administration of this sugar were comparable to those following sucrose and lactose.

The only statistically significant difference between the three curves shown in Fig. 1 is that the mean 30-minute blood sugar levels following sucrose administration were greater than those following lactose. This difference was common to all age 
groups studied. There are two possible explanations for this difference:

1. It might be argued that because galactose stimulates the release of insulin and fructose does not (Foa, Galansino, Costa and Pozza, 1956), the galactose released into the blood after hydrolysis of lactose had a depressant action upon the blood glucose. This is a recognized phenomenon in congenital galactosaemia in which condition high blood levels of galactose occur (Isselbacher, 1959). However, it has been shown that although some galactose must reach the systemic blood because of the frequent observance of galactosuria after lactose ingestion, the amounts were undetectable by the chromatographic method used. It is difficult to imagine that these small amounts of galactose, which must be less than $10 \mathrm{mg}$. per $100 \mathrm{ml}$. would exert an appreciable hypoglycaemic effect.

2. The method of King (1951) used for measuring total blood sugar is a 'true sugar' method but not a 'true glucose' method. Fructose was observed by paper chromatography in six of the 2230 -minute blood samples obtained from those children who ingested sucrose. Smaller amounts might have been present in more. Sucrose is not a reducing sugar and is not estimated by the King method. The 'sucrose curve' would therefore, be a measure of glucose and some fructose and the 'lactose curve' of glucose alone, since, as already stated, no other sugar was detected by chromatography in these blood samples. This seems the most reasonable explanation for the difference of the 30-minute blood levels in the two curves, although it does not explain why the 'sucrose curve' was not higher than the 'lactose curve' at other time intervals. In fact, the mean 15-minute blood sugar level of the latter curve was higher than the former although the difference is not statistically significant. This question could only be solved by repeating the experiments using the glucose oxidase method so that it would be known that only glucose and no other sugar was estimated.

It must be mentioned that these blood sugar curves should not be accepted without certain reservations. The subjects were not normal children; they were hospital patients and, although they were not suffering from any generalized acute illness at the time of the test, their glycaemic response to the sugars may not have been normal. It has been shown that the glucose tolerance test is abnormal in the presence of infection, even skin infection (Schmidt, Eastland and Burns, 1934). However, it is doubtful whether this factor would have caused the observed difference between the sucrose and lactose curves because the two groups of children who received these sugars were fairly evenly matched as far as their original illnesses were concerned. It is also known that the preceding carbohydrate diet has a great effect upon the glucose tolerance test (Himsworth, 1935). The subjects were not taking a controlled diet before the tests were performed. They were, however, all eating the standard hospital diet well and it is likely that their preceding carbohydrate intake was fairly uniform.

\section{Summary}

Forty-seven newborn babies and 47 older children were fed with the disaccharides lactose, sucrose or maltose. Subsequent urine collection showed a high sugar excretion rate.

The source of urinary hexoses and disaccharides is undoubtedly the gut, because a sugar was not found in the urine unless a feed containing that sugar, either free or in combination, had recently been fed. Small amounts of the disaccharides, lactose and sucrose, escape hydrolysis in the gut, are absorbed unchanged and subsequently excreted in the urine.

Although earlier work had suggested that premature babies excreted sugars to a greater degree than mature babies, this was not confirmed in the present series of observations. The degree of sugar excretion did not apparently depend on the maturity or age of the child or the dose of the sugar administered by mouth.

The finding of sucrosuria in one-third of the children who were given sucrose by mouth makes it unlikely that the sucrosuria that has been described in association with mental deficiency is anything more than a coincidence.

Sucrose and/or fructose were found in the blood of six children following a feed of sucrose, but these were not the same children who excreted this combination of sugars in the urine. Lactose was found in the blood of one child following a lactose feed, but galactose was not demonstrated on any occasion. This discrepancy between blood and urinary findings was almost certainly due to technical reasons.

Maltose was not found in the blood or urine following feedings of this sugar. The reasons why this disaccharide should behave differently from lactose and sucrose have been discussed. 
I wish to thank many physicians who have allowed me to examine patients under their care, and the nursing staffs of the Winnipeg Children's and General Hospitals who have helped in the collection of specimens. I am also grateful to $\mathrm{Mr}$. H. Birnboim for technical assistance, Dr. R. J. Cadoret for help with the statistical evaluation and Drs. H. Medovy, B. Chown, S. Israels and K. Finkel for their advice and criticism. This work was supported by a grant from the Winnipeg Clinic Research Institute and a Mead Johnson Grant for Paediatric Research administered by the American Academy of Pediatrics.

\section{REFERENCES}

Apthorp, G. H. (1957). Investigation of the sugar content of urine from normal subjects and patients with renal and hepatic disease by paper chromatography. J. clin. Path., 10, 84 .

Bickel, H. (1959). Zur klinischen Bedeutung verschiedener Melliturien. Mod. Probl. Paediat., Vol. IV, 136. Karger, Basel and New York.

Coant, J. G., Glowacki, F. and Reardon, H. S. (1959). Melituria of premature infants. A.M.A. J. Dis. Child., 98, 571.

Dodds, C., Fairweather, F. A., Miller, A. L. and Rose, C. F. M. (1959). Blood-sugar response of normal adults to dextrose, sucrose and liquid glucose. Lancet, 1, 485.

Dormandy, T. L., Leak, D. and Grant, M. (1959). Hypoglycaemia induced by galactose. Ibid., $2,269$.

Elmer, A. W., Krasowska, M. and Ptaszek, L. (1939). Sucrosuria, a rare metabolic error. Acta med. scand., 101, 596.

Field, C. W. (1919). Blood sugar curves with glucose, lactose, maltose, mannite and cane sugar. Proc. Soc. exp. Biol. (N.Y.), 17, 29.

Foa, P. P., Galansino, G., Costa, E. and Pozza, G. (1956). Regulation of insulin secretion by carbohydrates other than glucose. Fed. Proc. 15, 64

Folin, O. and Berglund, H. (1922). Some new observations and interpretations with reference to the transportation, retention, and excretion of carbohydrates. J. biol. Chem., 51, 213 .

Greenwald, H. M. and Pennell, S. (1930). The carbohydrate metabolism of the normal new-born infant. Amer. J. Dis. Child., $39,493$.

Hartmann, A. F., Grunwaldt, E. and James, D. H., Jr. (1953) Blood galactose in infants and children. J. Pediat., 43,

-, McCoy, E. E., Swarm, P. A. and Nakasato, D. I. (1954). Further observations on the metabolism of galactose in infants and children. Ibid., 44, 499

Haworth, J. C. and Ford, J. D. (1960). Blood sugar in infants after lactose feeds. Lancet, $2,794$.

- and McCredie, D. (1956). Chromatographic separation of reducing sugars in the urines of newborn babies. Arch. Dis. Childh., 31, 189

- and MacDonald, M. S. (1957). Reducing sugars in the urine and blood of premature babies. Ibid., 32, 417 .
Himsworth, H. P. (1935). The dietetic factor determining the glucose tolerance and sensitivity to insulin of healthy men. Clin. Sci., $2,67$.

Horrocks, R. H. and Manning, G. B. (1949). Partition chromatography on paper. Identification of reducing substances in urine. Lancet, 1, 1042.

Isselbacher, K. J. (1959). Galactose metabolism and galactosemia. Amer. $J$. Med., 26, 715.

Keith, N. M., and Power, M. H. (1937). The urinary excretion of sucrose and its distribution in the blood after intravenous injection into normal men. Amer. J. Physiol., 120, 203.

- Wakefield, E. G. and Power, M. H. (1932). The excretion and utilization of sucrose when injected intravenously in man. Ibid., 101, 63.

King, E. J. (1951). Micro-analysis in Medical Biochemistry, 2nd ed., p. 23. Churchill, London.

Koehler, A. E., Rapp, I. and Hill, E. (1935). The nutritive value of lactose in man. J. Nutr., 9, 715 .

Lahdensuu, S. (1947). On blood-sugar curves and saccharosuria in children due to saccharose tolerance test. Ann. Med. intern. Fenn., 36, 293.

Long, C. N. H. (1947). In Diseases of Metabolism. Edited by G. G. Duncan, 2nd ed., p. 20. Saunders, Philadelphia and London.

Moncrieff, A. and Wilkinson, R. H. (1954). Sucrosuria with mental defect and hiatus hernia. Acta paediat. (Uppsala), 43, Suppl. 100,495 .

Murschhauser, H. (1921). Welche Zuckerart wird von Säugling im Harne ausgeschieden, wenn die für ihn festgestellte Assimilationsgrenze für Rohrzucker in der Nahrung überschritten wird? Biochem. Z., 119, 328.

Owen, J. A. and Lewis, I. C. (1956). Sucrosuria in children. Scot. med. J., 1, 231.

Perry, T. L., Lippman, R. W., Walker, D. and Shaw, K. N. F. (1959). Sucrosuria and mental deficiency: a coincidence. Pediatrics, $24,774$.

Rabinowitch, I. M. (1945). Short period blood sugar time curves following ingestion of sucrose. J. Nutr., 29, 99.

_ and Mountford, M. (1947). Metabolism of sucrose: II. Amer. J. dig. Dis., 14, 315.

Reiner, M. and Weiner, S. B. (1939). Saccharosuria in an infant. Amer. J. Dis. Child., 57, 590

Rowe, A. W. (1924). The metabolism of galactose. Arch. intern. Med., 34, 388.

Rubin, M. I., Bruck, E. and Rapoport, M. (1949). Maturation of renal function in childhood: clearance studies. $J$. clin. Invest., 28, 1144.

Schmidt, E. G., Eastland, J. S. and Burns, J. H. (1934). Infection and the tolerance for dextrose. Arch. intern. Med., 54, 466.

Shay, H., Schloss, E. M. and Bell, M. A. (1931). The metabolism of galactose. Ibid., 47, 391 .

Williams, R. (1954). The chromatographic separation of reducing sugar in urine. J. med. Lab. Technol., 12, 43.

Winter, L. B. (1931). The metabolism of lactose. J. Physiol. (Lond.), 71, 341 .

Woodruff, G. G. (1958). Sucrosuria in association with mental deficiency and hiatal hernia. J. Pediat., 52, 66.

Woolf, L. I. (1951). Gt Ormond Str. J., 1, 61. Cited by Moncrieff and Wilkinson (1954). 